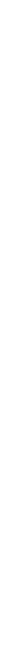

Between the Lines: The Language and Art of Death

Authors: $\quad$ Stephanie H. Lim, Jeremiah de Leon

Submitted: 23. August 2017

Published:

Volume:

Issue:

23. August 2017

4

3

Affiliation:

Keywords: $\quad$ visual arts; death; metaphor

DOI: $\quad 10.17160 /$ josha.4.3.311

Journal of Science,

Humanities and Arts 


\title{
Between the Lines: The Language and Art of Death
}

Stephanie H. Lim *1,2,3, MBBS and Jeremiah de Leon ${ }^{4}$, MBBS

${ }^{1}$ Department of Medical Oncology, Macarthur Cancer Therapy Centre, Campbelltown, Australia, ${ }^{2}$ Western Sydney University, Campbelltown, Australia, ${ }^{3}$ University of New South Wales, Kensington, Australia, ${ }^{4}$ Department of Radiation Oncology, Illawarra Cancer Care Centre, Wollongong, Australia

*Corresponding author:

Dr Stephanie Hui-Su Lim, MBBS, FRACP, PhD

Department of Medical Oncology

Macarthur Cancer Therapy Centre

Therry Rd, Campbelltown NSW 2560 Australia

Phone: +61-2 46344366

Fax: $+61-246344380$

Email: stephanie.lim@sswahs.nsw.gov.au

\begin{abstract}
This short paper reflects on the attitudes that modern society has towards death, which affect and form the language that we use to describe death. The key domains of concern to the dying are described, as well as the patterns of social interactions. It explores how the visual arts can offer an alternate and cathartic form of communication of death, as shown by the patient experience with cancer. Ultimately, it encourages us to view medicine as an art, and also art as medicine.
\end{abstract}

Keywords: visual arts; death; metaphor 


\section{Between the Lines: The Language and Art of Death}

As clinicians, we have patients we never forget. The emotions they evoked as we walked with them through their journey are etched into our subconscious. More than ten years on, I remember Mary and Jane well.

Mary was twenty-six. She exercised, kept a healthy diet, worked hard. She did all the things we tell our patients to do. She said at her clinic consultation that her splenomegaly was 'probably just glandular fever'. Mary would spend the majority of her remaining life confined to a hospital ward facing a disease she would eventually die from - Natural Killer Cell Leukaemia. How do you conquer something named a 'Natural Killer'?

Jane was in her forties with a teenage daughter. We were both art lovers. She spoke about life while I administered her intrathecal chemotherapy. Jane had accepted her fate, though not in words we doctors always look for, but through her art. Jane could explain deeper emotions through canvas than conversation.

Mary made it home for a few days to celebrate her last Christmas. She passed away surrounded by her mother and step-sisters. Jane died alone in hospital, arresting during the night after her daughter had left for the day.

Even in today's society, death remains a subject shrouded by taboo. I often feel the hardest conversation Mary had about death was not with her doctors or family, but with herself. Jane used art to communicate these emotions. How do we as clinicians, or as human beings, discuss death or the so-called "night-side of life"? (Sontag, 1978) How can we read between the lines so our patients can also see the big picture?

\section{Our Attitudes towards Death}

In order to understand the challenges we face in talking about death, we need to understand society's attitudes towards death. Philippe Aries, a French cultural historian, defined the four patterns in western society's attitudes toward death as tame death, death of the self, forbidden death and death of the other (Ariès, 1982). 'Tame death' is the oldest concept, and addresses death as a calm acceptance of the inevitable, consistent with the adage "all people die", as many of our elderly patients often tell us. 'Death of the self' arose around the $11^{\text {th }}$ to $13^{\text {th }}$ centuries, 
and questioned the after-life and saw the development of "ars moriendi" or the art of dying. The 18 th and $19^{\text {th }}$ centuries saw the rise of 'forbidden death' which was romanticised. Mourning became an art and death was even celebrated. 'Death of the other' is a concept of the $20^{\text {th }}$ century, where the dead was differentiated from the living as "the other". Death was socially unacceptable, resulting in a displacement of dying from the home to institutions. Geoffrey Gorer in the 1960's coined the phrase "pornography of dying" to capture these attitudes (Gorer, 1977).

Mary's attitudes toward death were shaped by her age, life experience and societal influences. In today's society, the mention of the word 'death' is commonly met with disbelief, denial and defeat. I often wonder whether the language we used could have made a difference to Mary's journey.

\section{Communicating Death: Learning from the Past}

Overcoming the metaphors surrounding death and talking to patients about death is an art, most evident to me whilst working in palliative care. Palliative care had existed before the antibiotic era, and strives to deal with quality of life at its end, and is often the first to begin the conversation about death and dying. The first modern hospice dates back to the late 1960's in London, pioneered by the work of Saint Christopher. It is sobering to note that many values integral to modern good bedside medicine predate the era where cure became the primary focus. Perhaps we need to step back and rediscover these skills.

These domains integral to modern palliative care were described by Peter Singer in 1999 (Singer et al., 1999). These include patients' sense of control and autonomy over their passing, adequate relief of pain and symptoms, avoiding inappropriate prolongation of death, relieving others of the burden of their dying and strengthening personal relationships. As clinicians, these are issues we need to talk about with our patients. Perhaps Mary needed to feel a sense of control, while Jane needed to relieve her daughter the burden of her dying.

As early as the 1960s, Barney Glaser and Anselm Strauss studied patterns of communication with the dying and described four categories of social interactions: closed awareness, suspected awareness, mutual pretence and open awareness (Glaser and Strauss, 1966). These four categories represent a continuum and the typical real-life scenario is one which starts out with a degree of closed awareness and often mutual pretence or suspected awareness, before 
progressing to a willingness to discuss and prepare for impending death. Cultural differences and the length of time certainly impacts on this progression. Mary did not have a lot of time. She passed away with dignity, but perhaps the conversation about death could have been started earlier on.

\section{Art as a Means of Communication}

The question arises as to why the visual arts is able to provide a cathartic form of expression. Morality has been viewed as the common ground between healing or death and the arts. Art develops our perceptions, encourages us to engage with the viewer, and allows us to express the vulnerable on a tangible medium. Through this, we develop empathy, sympathy and are better able to convey the doctor-patient relationship.

Figures 1 to 3 represent some examples of how art conveys death. These artworks communicate the subject matter with a clarity expressed on a blank canvas. Edvard Munch, in Dead Mother and Child, depicts a young girl who has her back turned to her dead mother who lies in bed. The mourners pay no attention to her anxiety as they perform their rituals. Perhaps this depicts forbidden death, as the young girl deals with death on her own. In another painting By the Deathbed, there is a suggestion of acceptance of the truth, as the woman in the back looks straight at the viewer. This painting reminds me of Jane.

Robert Pope was a patient with Hodgkins Disease and an artist, who often depicted the view of the hospital from the patient's perspective, showing medical paternalism and the paraphernalia of treatment. In Chemotherapy, the fear and alienation are depicted by the perspective of the lone subject facing the viewer and disproportionate scale of the large syringe and needle in the foreground. I often wonder if I were on the other side of the consultation table whether I would paint the same picture. Jo Spence depicts a similar vulnerability to breast cancer, showing the helplessness and objectification of the patient in the hospital environment. She steps beyond this, and reclaims herself in her art. As she states: "By using photography, throughout my illness, it meant that certain facets of my history were planted squarely and visibly in front of me". She was able to express the autonomy over her body and sense of control. As Robert Pope puts it: "Art is powerful preventative medicine....ultimately the aesthetic experience heals us". Perhaps we need to step outside the box, and engage our patients in the conversation of death, whether in words or another form of artistic expression. 


\section{Between the Lines}

Mary and Jane both taught and challenged me to think about death, and break down attitudes surrounding death in medicine. As the $16^{\text {th }}$ century aphorism puts it so accurately - the role of a physician is "to cure sometimes, to relieve often, to comfort always".

Jane teaches us another means of expression as a form of therapy. It has been said that art infiltrates the patient's consciousness, that it portrays "the night-side of life" (Sontag, 1978). Marie Therese Southgate, physician and former senior editor of the Journal of The American Medical Association, puts it simply: "Medicine and art have a common goal: to complete what nature cannot bring to a finish, to reach the deal, to heal creation. This is done by paying attention. The physician attends to the patient, the artist attends to nature. Art, like medicine, is not an arrival; it's a search". The lesson, whether it is the art of medicine, or medicine in the arts, is always found in paying attention to our patients. In striving to cure, we should never forget about caring, especially when cure is no longer attainable. We should never stop to learn from our patients, who teach us to read beyond the prescription of chemotherapy, the results of tests. They teach us to read, or draw, between the lines. 


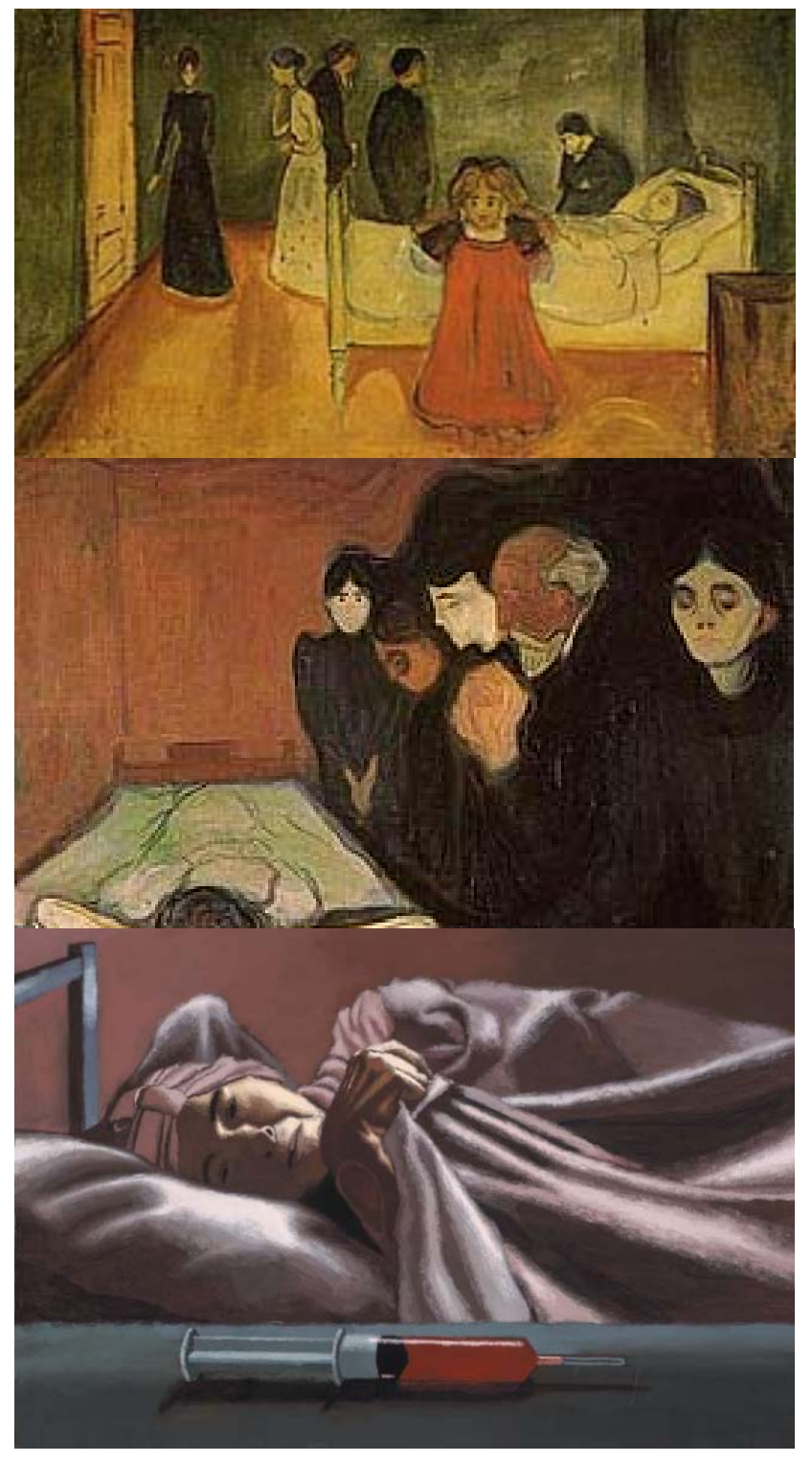

Figure 1 (top): Edvard Munch, The Dead Mother and Child, 1897-9, Oil on canvas; Figure 2 (middle): Edvard Munch, By the Deathbed, 1895, Oil on canvas; Figure 3 (bottom): Robert Pope, Chemotherapy, 1989, acrylic on canvas.

\section{Acknowledgements}

The authors declare no conflicts of interest. 


\section{Curriculum Vitae for Stephanie Lim}

\section{Academic Qualifications}

2017

2017

2013

2013

2010

2006

2002

Employment

2016

2016

2015-16

2011-12

2009-10

2008

2013-15 Research and Clinical Fellow

$\mathrm{PhD}$ of medicine, University of New South Wales

Appointment as conjoint lecturer, Western Sydney University

Admission to Fellowship of the Royal Australasian College of Physicians (FRACP)

Appointment as conjoint lecturer, University of New South Wales

Completion of RACP written and clinical examinations

Bachelor of Medicine and Bachelor of Surgery (Honours)

University of Sydney

Bachelor of Medical Science, University of Sydney

Ingham Research Institute and Liverpool Hospital

Medical Oncology Advanced Training

Basic Physician Training

Residency 
Dean's List Award 2015, University of New South Wales

2015

Nominated for Cancer Institute NSW Premier Award for "Rising Star PhD student"

2015

South Western Sydney Local Health District and Ingham Institute Research Scholarship

Postgraduate Research Support Scheme award, University of New South Wales

Ingham translational colorectal cancer scholarship

Trainee Annual Scientific Meeting Travel Award, in conjunction with the Medical Oncology Group of Australia

Faculty of Medicine International Merit Scholarship

Faculty of Science International Merit Scholarship

2002

Dean's Honour List for Bachelor of Medical Science

2001

Faculty of Science International Merit Scholarship

Dean's Honour List for Bachelor of Medical Science

\section{Publications}


1. $\quad$ SH Lim, W Chua, C Henderson, W Ng, J-S Shin, L Chantrill, R Asghari, CS Lee, KJ Spring and $\mathrm{P}$ de Souza. Predictive and prognostic biomarkers for neoadjuvant chemoradiation in locally advanced rectal cancer. Critical Reviews in Oncology/Hematology 2015, doi:10.1016/j.critrevonc.2015.05.003

2. T. G. Tut, S. H. S. Lim, I. U. Dissanayake, J. Descallar, W. Chua, W. Ng, P. de Souza, J-S and Shin, C. S. Lee. Upregulated Polo-like Kinase 1 Expression Correlates with Inferior Survival Outcomes in Rectal Cancer. PLOS One, 2015 Jun 5;10(6):e0129313. doi: 10.1371/journal.pone.0129313 (Joint $1^{\text {st }}$ author publication)

3. $\quad$ S.H. Lim, T.M. Becker, W. Chua, W.L. Ng, P. de Souza, K.J. Spring. Circulating tumour cells and the epithelial mesenchymal transition in colorectal cancer. J Clin Pathol. 2014 Jul 9. pii: jclinpath-2014-202499. doi: 10.1136/jclinpath-2014-202499

4. $\quad \underline{\text { Lim SH}}$, Becker TM, Chua W, Caixeiro NJ, Ng WL, Kienzle N, Tognela A, Lumba S, Rasko JE, de Souza P, Spring KJ. Circulating tumour cells and circulating free nucleic acid as prognostic and predictive biomarkers in colorectal cancer. Cancer Letters 2014; 346 (1): 24-33; doi: 10.1016/j.canlet.2013.12.019

5. $\quad$ S.H. Lim, S. Ardern-Holmes, G. McCowage, P. de Souza. Systemic Therapy in Neurofibromatosis Type 2. Cancer Treatment Reviews 2014; 40: 857-861; DOI: 10.1016/j.ctrv.2014.05.004

6. $\quad$ S.H. Lim, K.J. Spring, P. de Souza, S. MacKenzie, L. Bokey. Circulating tumour cells and circulating nucleic acids as a measure of tumour dissemination in non-metastatic colorectal cancer surgery. European Journal of Surgical Oncology 2014; 34: 6505-13

7. $\quad$ S.H. Lim, G. P. Delaney, J. Descallar, P. Sayaloune, G. Papadatos, P. de Souza. Outcomes of Ethnic Minority Groups with Node-positive, Non-metastatic Breast Cancer in Two Tertiary Referral Centres in Sydney, Australia. PLOS One; doi: 10.1371/journal.pone.0095852 
8. Stephanie H. Lim, Wei Chua, Christina Cheng, Joseph Descallar, Weng Ng, Michael Solomon, Les Bokey, Karen Wong, Mark T. Lee, Paul de Souza, Joo-Shik Shin, Cheok Soon Lee. Effect of Neoadjuvant Chemoradiation on Tumour Infiltrating/associated Lymphocytes in Locally Advanced Rectal Cancers. Anticancer Research 2014; 34 (11): $6505-13$

9. $\quad$ S.H. Lim. 2015, Rectal Cancer in M. Schwab (ed), Encyclopedia of Cancer, Springer reference

10. Lim S and de Souza P. Imatinib in neurofibromatosis type 2. BMJ Case Rep. 2013; doi: 10.1136/bcr-2013-010274

11. Lim SH, Wilson SM, Hunter A, Hill J, and Beale PJ. Takotsubo cardiomyopathy and 5fluorouracil - getting to the heart of the matter. Case Rep Oncol Med. 2013; doi: $10.1155 / 2013 / 206765$

12. Bae K, Park J-H, Kim J, Cho C-K, Oh B, Costa D, Lim S, Deng G and Yoo H-S. Traditional oriental herbal medicine and natural killer cells for cancer patients: a systematic review and meta-analysis. 2017; doi: 10.1002/ptr.5781

13. Oh B, Figtree G, Costa D, Eade T, Hruby G, Lim SHS, Elfiky A, Martin N,Rosenthal D, Clarke S and Back M. Oxidative Stress in Prostate Cancer Patient: A Systemic Review of Case Control Studies. Prostate International. 2016; doi: 10.1016/j.prnil.2016.05.002

14. N.J. Caixeiro, N. Kienzle, S.H. Lim, K.J. Spring, A. Tognela, K. F. Scott, P. de Souza, T.M. Becker. Circulating tumor cells - a bona-fide cause of metastatic cancer. Cancer metastasis reviews; doi: 10.1007/s10555-014-9502-8 
15. Becker TM, Caixeiro NJ, Lim SH, Tognela A, Kienzle N, Scott KF, Spring KJ and de Souza P. New frontiers in circulating tumor cell analysis: A reference guide for biomolecular profiling toward translational clinical use. Int. J. Cancer. 2014; 134 (11): 2523-33; doi: 10.1002/ijc.28516

16. A. Tognela, K.J. Spring, T. Becker, N.J. Caixeiro, V.J. Bray, P.Y. Yip, W. Chua, S.H. $\underline{\text { Lim, }}$ P. de Souza. Predictive and prognostic value of circulating tumor cell detection in lung cancer: A clinician's perspective. Critical Reviews in Oncology/Hematology 2015; 93(2): 90-102

\begin{abstract}
s
Presented more than 20 abstracts in oral and poster form in international and national conferences including ASTRO, ESMO, AACR.
\end{abstract}

\title{
References
}

ARIÈS, P. 1982. The Hour of Our Death: The Classic History of Western Attitudes Toward Death over the Last One Thousand Years.

GLASER, B. G. \& STRAUSS, A. L. 1966. Awareness Of Dying, Transaction Publishers.

GORER, G. 1977. Death, Grief, and Mourning, Arno Press.

SINGER, P. A., MARTIN, D. K. \& KELNER, M. 1999. Quality end-of-life care: patients' perspectives. JAMA, 281, 163-8.

SONTAG, S. 1978. Illness as metaphor, United States, Farrar, Straus \& Giroux. 